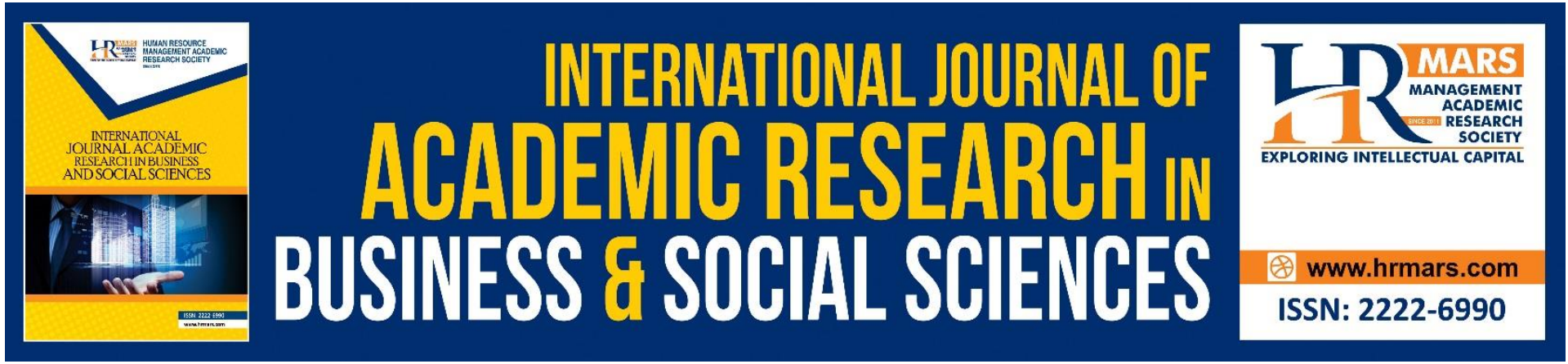

\title{
Revisiting the Challenges Affecting SMEs Through Behavioral Approach
}

Mohamed Shekar, Mazlan Hassan, Muneer Al Mubarak

To Link this Article: http://dx.doi.org/10.6007/IJARBSS/v11-i9/10753 DOI:10.6007/IJARBSS/v11-i9/10753

Received: 12 July 2021, Revised: 16 August 2021, Accepted: 20 August 2021

Published Online: 09 September 2021

In-Text Citation: (Shekar et al., 2021)

To Cite this Article: Shekar, M., Hassan, M., \& Al Mubarak, M. (2021). Revisiting the Challenges Affecting SMEs Through Behavioral Approach. International Journal of Academic Research in Business and Social Sciences, 11(9), 234-258.

Copyright: (C) 2021 The Author(s)

Published by Human Resource Management Academic Research Society (www.hrmars.com)

This article is published under the Creative Commons Attribution (CC BY 4.0) license. Anyone may reproduce, distribute, translate and create derivative works of this article (for both commercial and non-commercial purposes), subject to full attribution to the original publication and authors. The full terms of this license may be seen

at: http://creativecommons.org/licences/by/4.0/legalcode

Vol. 11, No. 9, 2021, Pg. 234 - 258

http://hrmars.com/index.php/pages/detail/IJARBSS

JOURNAL HOMEPAGE

Full Terms \& Conditions of access and use can be found at http://hrmars.com/index.php/pages/detail/publication-ethics 


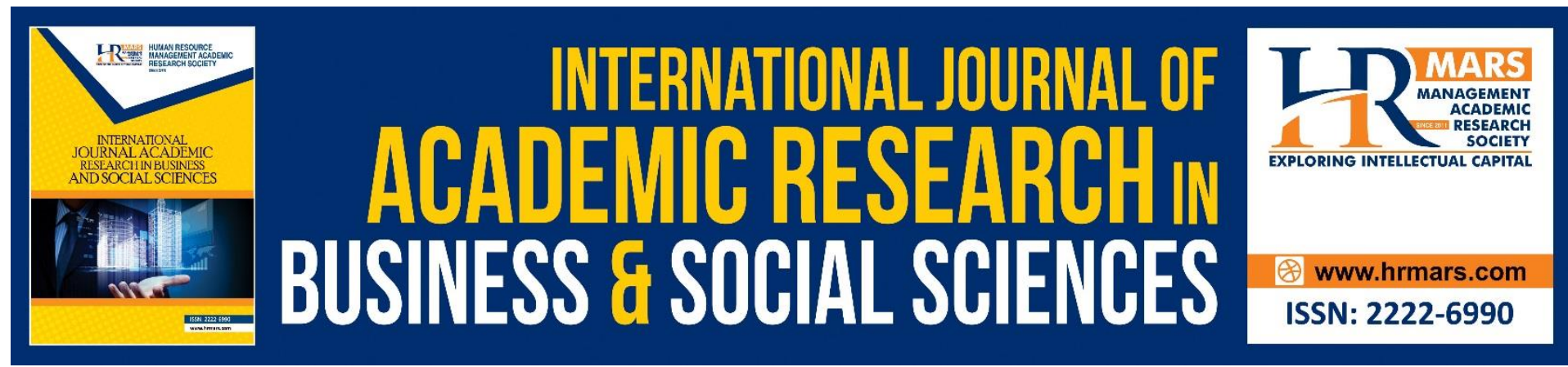

\title{
Revisiting the Challenges Affecting SMEs Through Behavioral Approach
}

\author{
Mohamed Shekar, Mazlan Hassan, Muneer Al Mubarak \\ ${ }^{1,2}$ School of Business and Economics, University Putra Malaysia (UPM), ${ }^{3}$ College of Business \\ \& Finance, Ahlia University
}

Email: gs53732@student.upm.edu.my,mazlanhs@upm.edu.my,malmubarak@ahlia.edu.bh

\begin{abstract}
The main aim of this study is to investigate the key challenges affecting small and medium enterprises (SMEs). Simultaneously, it would also discuss the background of those challenges, as well as recognizing the challenges that could be controlled by SMEs, and to propose a model. The paper is exploratory in nature and stands on secondary sources. The data are inclusive of scholarly and publicly sources. The data analysis is built on critical content analysis and theming process. Three figures are presented to demonstrate the methodology of study, the suggested model, and the linkage between the findings of study with the corresponding proposed constructs. The study recognizes six internal and external challenges that affect the SMEs. Resources management, entrepreneurial behavior, SMEs capabilities, problem solving and decision making, as well as leadership are the internal factors. The complexity of the business environment and social influence are external factors. It is found that SMEs organizational behavior is the principal domain behind these challenges. The study suggests practitioners should follow specific behavioral strategies such as entrepreneurial management (EM), transformational leadership ( $T L)$, strategic improvisation (SI), and dynamic capabilities (DCs) to overcome the different challenges and scale up their positions. As for the promoters, stimulating entrepreneurship among people and revising the training courses should be conducted to cope with market needs.
\end{abstract}

Keywords: Small Business, Small and Medium Sized Enterprises, Smes, Challenges, Obstacles, Entrepreneurs, Entrepreneurship, Organizational Behavior, SMES Behavior.

\section{Introduction}

SMEs represent 90 percent and weigh more than 50 percent of employment worldwide (World Bank, 2021). They are able to offer a wider range of job opportunities in terms of different specializations than what large-organizations normally create as a medium to bring out new technologies, operational knowledge, and innovative products (Khan \& Khalique, 2014). Most developing countries have positioned their interests on stimulating SMEs to drive socioeconomic improvements. So far, they share over 55 percent of the GDP and over 65 percent of employment in those nations (Akbar et al., 2018). Bahrain and the other members of the Gulf Cooperation Council (GCC) are no exception as they wish to reduce the reliance on the oil revenues (Al-Dairi et al., 2012; Nakibullah, 2018). 
The available literature has not discussed the SMEs challenges from the behavioral perspective adequately. Most researchers discuss the behavior of individuals, such as employees (Youssef \& Luthans, 2007; Zavadsky et al., 2020), and owners (Kijkasiwat, 2021). Yanes-Estévez et al (2018) study the strategic behavior of SMEs by identifying three problems; namely entrepreneurial, technological, and administrative. Rubio and Aragon (2009) investigate the success factors rather than the problems of SMEs. Besides, there is deficiency of the studies that identify the challenges that could be controlled by SMEs. Therefore, the current study tries to fill in important gaps by revisiting SMEs challenges from another perspective and verify controllable problems prior to providing corresponding suggestions. Furthermore, this study paves a path for future studies to test the important assumptions and relationships.

Organizations for Economic Co-operation and Development (2018, p.16) advocates a "greater international cooperation is required to identify global solutions to global challenges of SMEs". However, Paul et al (2017) mention that there are possibilities to conduct studies in developing countries because most studies are conducted in developed ones. Pissarides (1999) also asserts that the location is important in these studies because constrains are classified in two broad sets: a common set-in similar country, and the other one is countryspecific. This study believes conducting more studies from different contexts is important to facilitate comparative studies in future.

Bahrain is chosen because its entrepreneurship model is recognized by United Nations Industrial Development Organization as the best in the world (Chaaban, 2015). Forty-two countries have already followed Bahrain's model and others are on the way (AlSoufi, 2016). Thus, investigating in the Bahrain context is beneficial from different perspectives.

Previous researches that have conducted investigation on Bahrain SMEs are either fragmented into different directions or on selected portions such as women gender (Sadi \& AlGhazali, 2012; AlGhazali et al., 2013; Hasan and Almubarak, 2016; Dutta, 2017), marketing perspective (Alsamari et al., 2013), external dimensions (Dunn \& Bradstreet; 2008; Alrabeei \& Kasi, 2014), and/or international business (AlRabeei \& Scott, 2011; Alyafie \& Almubarak, 2016). Consequently, there is a lack on the literature on Bahrain that looks into the sector from both internal and external sides regardless the gender or the sectorial classifications. Thus, this is another gap that needs to be filled in.

The paper is organized as follows. First, the review of the literature on challenges faced by SMEs is presented. Then, the discussion on the research methodology is employed for data analysis. Subsequently, the findings are presented, followed by a separate section to discuss and relate the findings with previous studies. Next, the proposed model is presented to draw a conclusion, and provide implications of the results. In the end, limitation of the current study and recommendation for future research are offered.

\section{Literature Review}

The relevant literature is obtained on online database such as Google Scholar, Scopus, ProQuest, Elsevier. Specific keywords such as SMEs challenges, SMEs problems, SMEs obstacles, SMEs issues, and SMEs barriers are outlined accordingly in this section. Two approaches are observed to investigate the SME, namely,: dimensional and geographical. 


\section{i) Dimensional Problems}

There is an increasing research that indicates SMEs are faced with multifaceted problems in the contemporary business environment. For this reason, Uden (2007) suggests considering multiple threats and opportunities related to suppliers, buyers, products and services. Similarly, Agwu (2014) reports that the vast majority of SMEs vanish after five years of operation because of the initial infrastructure aspects such as water supply, transportation network, electricity, and waste management system. The multiple taxations, access to finance and the unstable policy on environment are other important factors that influence the situation. Serefoglu and Gokkaya (2017) state that $82 \%$ of Turkish SMEs do not export because of administrative and legal obstacles, lack of finance, and technical staffing.

Other researchers have classified the different problems as either internal or external. Wang (2016) posits the factors could be clustered as "internal" or "external". On the one hand, internal factor which is also referred as micro, indicate issues that are controllable by the firm (Fatoki, 2014). On the other hand, external factor which is also referred to as macro, are beyond the firm's control (Paul et al., 2017; Wang, 2016).

Andalib and Halim (2019) conclude the internal challenges are managerial inexperience, lack of innovation performance and employees rights, Whereas, the external are regulatory licenses and taxes. Fatoki (2014) discovers internal lack of management experience, functional skills and poor attitudes towards customers are key challenges, while unavailability of a logistics chain, high cost of distribution, competition, rising costs of doing business, lack of finance and crime are the external issues. On contrary, Latha and Murthy (2009) conclude there are internal obstacles which are inherited within the SMEs such as technical and managerial assistances, marketing of products and absenteeism of labor. While the external challenges act as threats against the SMEs, which include the price of raw materials, lack of market information, competition, and access to finance.

On one hand, some researchers give higher attention to SMEs leaders perception which resulted in unbalanced conclusions that motivate to external issues. Since McCannand and Ortega-Argiles (2016) study is designed based on external parameters, they recommend involving SMEs leaders in the process of creating policies and public interventions. While, Sanyal et al (2020) conclude the problems faced by SMEs are purely external (finance availability, market access, and business environment), Yoshino and Taghizadeh-Hesary (2016) suggest only external solutions could override the SMEs problems by improving the financing schemes and enabling access to information.

Another example is the study conducted by Cant and Wiid (2013) who aim to investigate the effect of macro variables on SMEs depending on SMEs perception. They conclude that external factors are accountable the SMEs' failure, namely because of the borrowing cost, crime, and demand. While the incorrect pricing, and location of business are two minor internal factors listed.

In an advanced level within the external stream, some researchers seem to be inclined to the governmental role. While Gunerergin et al (2012) conclude government is responsible of various external challenges such as the unfair competition, the institutionalization process and the financing difficulties. Tran (2015) suggests SMEs need substantial support from the 
governments with regards to the official processes, credit access, and business environment. Likewise, Al-Maskari et al (2019) reports a list of internal and external challenges. Nevertheless, they recommend only governmental interventions to mitigate the external problems, without mentioning any solution for the internal issues.

On the other hand, the internal stream advocates a firm could overcome many obstacles by improving the internal settings (Andalib \& Halim, 2019; Tran, 2015). Agwu (2014) urges to look from inside as there is significant impact of management, human resources, and marketing. Specifically, for those SMEs which lack the core skills, empowerment should be given to the overall business management. Likewise, Farsi and Toghraee (2014) believe innovation is the missing part that hinders most SMEs from performing well.

A group of scholars trust the improved internal capabilities could mitigate even external problems. They describe external issues, such as distributers, communicating with customers and human resources are influential factors in the situation. Paul et al (2017) consider these as internal problems and believe SMEs could control them by improving the networking, new market conditions, technological developments and the capabilities of managerial team and/ or the entrepreneurs. Literally, Paul et al. (2017) describe the status of external effects as the result from the inter-firm productive linkages.

Džafić et al (2011) report a total of twenty problems are encountered by SMEs in Bosnia and Herzegovina. Nonetheless, they believe entrepreneurs and managers could eliminate the internal obstacles and reduce external obstacles. Equally, Uden (2007) believes SMEs management could enter different marketplaces, shrink the supply chain, support the internal process, improve the image of the company, and cut-off multiple costs if they embrace four strategies, namely: E-business, globalization, integration of technology, and networking. In turn, Vrande et al. (2009) suggest that, through the open innovation techniques, SMEs would be capable to overcome many external threats.

\section{ii) Geographical Based Studies}

There are increasing attempts to investigate SMEs problems based on specific countries or regions for the purpose of generalizing either problems or solutions in contexts that share similar characteristics.

In developing nations, Wang (2016) analyzes the barriers of growth throughout 119 countries and reveals that access to finance is the supreme barrier. Kumarasinghe (2017) explores hindering and fostering factors in Sri Lanka and identifies eight obstacles:- leaders' attitude, financial issues, labor availability, technology issues, entrepreneurial knowledge, feasibility study, and government support. Whereas, the raw material availability and government support are the success factor. Coad and Tamvada (2012) extract eight factors that are believed to affect the Indian SMEs: lack of demand, shortage of working capital, unavailability of raw materials, power shortage, other problems in labor, marketing, equipment, and management.

In developed nations, however, Ericson et al (2016) explore challenges and necessities of SMEs in Finland, Norway and Sweden and discover that the common problems are access to regional resources, applying new strategies, and lunching modern products. In turn, Battistella et al. (2018) study the business models of SMEs in Italy and outline the various barriers. On one hand, the external problems are directly related to the limitation of financial 
and human resources, organizational structure and culture, management capabilities, and lack of entrepreneurial skills. On the other hand, the external barriers are the inadequate external inducements from governments and the marketplace.

Noticeably, there is a dearth of researches that compare the various problems between different nations. The work done by lhua (2009) is one of few which compare a developed nation (UK) with another developing one (Nigeria). Ihua examines ten variables and found the theme of failure problems in UK is internal; namely poor management, while major problems in Nigeria are poor economic conditions and infrastructural inadequacy; which are external issues. Besides, Ihua reveals common problems in both countries as a mixture of external (e.g. financial, and disasters) and internal issues (e.g. planning, and poor marketing).

\section{Research Methodology}

Based on an inductive approach, this study relies on multiple secondary sources to investigate the SMEs sector in Bahrain. In particular, the source channels for data are both scholarly sources (journal articles and conference papers, and theses) and publicly available data (press reviews, websites, institutional reports, and government publications) which are used to utilize important statements and feedback that are provided by top executives in Bahrain SMEs sector.

As illustrated in figure 1, firstly, the different kind of sources available about Bahrain SMEs in the last two decades are collected. Next the most relevant public data and sources are refined. Then the public sources are exposed to investigate intensively to understand the current situation of Bahrain SMEs and extract important information. Later, critical content analysis is applied to the scholarly sources to find out what are the gaps that need to be sorted out; and finally, a matrix which contains the information extracted is filled and then the findings are reported in theme style to draw specific factors. 


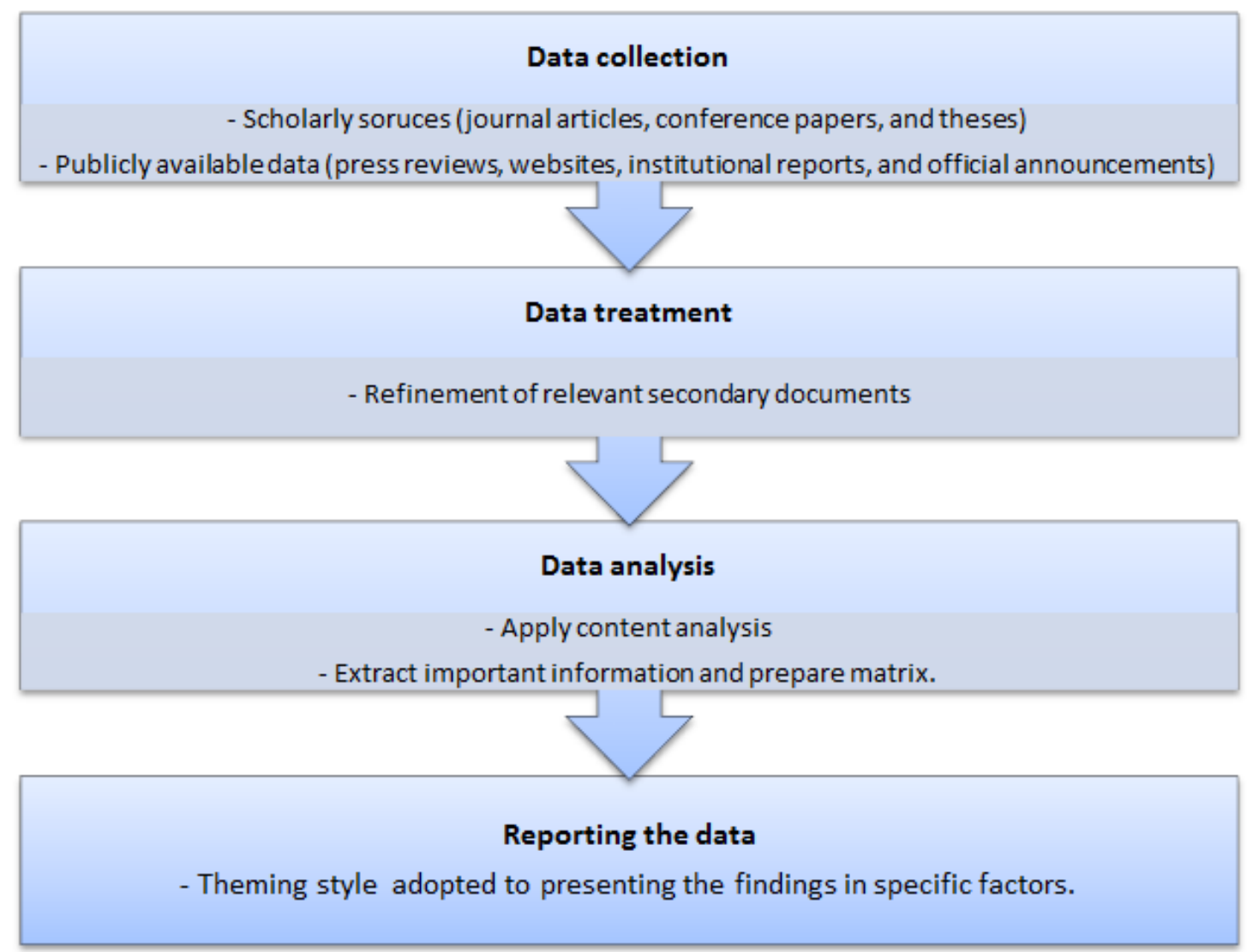

Figure-1 Methodology

\section{Findings of Study}

Since 2000 Bahrain's government has been delivering an outstanding business support to SMEs sector, and it endows them all with the ingredients required for success (Ravi, 2017). Nonetheless, while it makes up more than $98 \%$ of all commercial establishments registered (Ministry of Industry Commerce and Tourism, 2020), the sector contributes 25\% to the country's GDP (Townsend, 2017), 8\% of the national exports (BNA, 2018), 56\% of the overall labor forces (Khamis, 2016), and $11 \%$ of the national employment (AlSoufi, 2016). Accordingly, Bahrain SMEs do not seem to have a proportionate impact on the economy with undesirable performance (Alrabeei \& Kasi, 2014; Townsend, 2017) conducive to recession (Economic Development Board, 2018). Consequently, the following themed problems are contended as being the key reasons behind any unwanted situation.

\section{i. Resources Management}

Bahrain SMEs face difficulties in securing resources (Ravi, 2017; Bunagan \& Sison, 2018). On one hand, the scarcity of qualified HR is the key barrier that hinders Bahrain SMEs from growing (Dun \& Bradstreet, 2008; Alrabeei \& Kasi, 2014; Hasan \& Almubarak, 2016). On the other hand, limited finance is extensively cited at a local stage (AlRabeei \& Scott, 2011; Ashoor, 2013; Alsamari et al., 2013; Alrabeei \& Kasi, 2014; Khamis, 2016), the matter that denotes lack of access (AlRabeei \& Scott, 2011; Ashoor, 2013; Alsamari et al., 2013; Alrabeei \& Kasi, 2014; Khamis, 2016), and insufficient funding schemes (Kaufman, 2013; Darwish, 2014).

Despite the fact that some papers justify the funding problem to the high borrowing cost, collateral requirements, poor book keeping, or accounting practices (Dun \& Bradstreet, 2008; 
Darwish, 2014; AlSoufi, 2016), are all part of the financial management as lenders embrace cautious strategy against the SMEs in response to their financial management failure (BNA, 2013; Ravi, 2017).

\section{ii. Complicated Business Environment}

Bahrain's market is opened and one of the permitted in the world (AlRabeei, 2003; Nakibullah \& Islam, 2007). It is, nonetheless, the smallest in GCC (AlRabeei \& Scott, 2011; Hamdi \& Sbia, 2013), with a GDP of USD 34 billion only (Dauphin et al., 2016). Therefore, the density of business establishments per inhabitant is high (Ashoor, 2013; Kasi, 2016), the matter that denotes a fierce competition which has been growing rapidly amongst the SMEs (Chaaban, 2015; Alrabeei \& Kasi, 2014; Alrabeei \& Scott, 2014; Gillett, 2016; Nakibullah, 2018), and, in fact, is believed to contribute to minimizing business opportunities (Bahrain Chamber of Commerce and Industry, 2016).

\section{iii. Entrepreneurial Behavior}

Four dimensions have been observed to describe the entrepreneurial behavior of Bahrain SMEs, namely: growth orientation, opportunity seeking, risk taking, and the response to social influence.

According to MOICT (2020) out of 50,650 SMEs, there are 36,729 micro, 13,035 small, and 886 medium enterprises.

Table-1 Sectorial Distribution of Enterprises

\begin{tabular}{|l|l|l|l|}
\hline \multicolumn{1}{|c|}{$\begin{array}{c}\text { Enterprise } \\
\text { size }\end{array}$} & \multicolumn{1}{|c|}{$\begin{array}{c}\text { No. of } \\
\text { enterprises }\end{array}$} & \multicolumn{2}{|c|}{$\begin{array}{c}\text { Percentage } \\
\%\end{array}$} \\
\hline Micro & 36,729 & 71.37 & \\
\hline Small & 13,035 & 25.33 & 98.42 \\
\hline Medium & 886 & 1.72 & \\
\hline Large & 811 & \multicolumn{2}{|c|}{1.58} \\
\hline Total & 51,461 & \multicolumn{2}{|c|}{100} \\
\hline
\end{tabular}

Source: MOICT (2020)

Table 1 shows that micro enterprises hold the major share of Bahrain SMEs. Indeed, they strive to grow and expand (Ravi, 2017) because of the lack of entrepreneurial qualities such as vision (AlRabeei \& Scott, 2011; Ravi, 2017), networking (Alrabeei, 2003), specialized advice (Ashoor, 2013), and growth strategy (Alsamari et al., 2013; Alrabeei \& Kasi, 2014; Alrabeei \& Scott, 2014). In other words, they lack the sight of when and how to grow (Kaufman, 2013; AlSoufi, 2016).

Furthermore, most SMEs do not enhance their designs of products and services (Alrabeei \& Kasi, 2014; Alrabeei \& Scott, 2014), and they lack both production creativity and innovative process (AIRabeei \& Scott, 2011; Gillett, 2016) and are unable to meet the quality standards of the market segments (Alyafie \& AlMubarak, 2016). 
Table-2 Top Three Industries in Term of SMEs Number

\begin{tabular}{|c|l|c|c|c|c|}
\hline \multirow{2}{*}{ SI } & \multirow{2}{*}{ Industry } & \multicolumn{4}{|c|}{ Year/ Percentage \% } \\
\cline { 3 - 6 } & & 2010 & 2014 & 2018 & 2020 \\
\hline 1 & Trading & 42 & 43 & 37 & 33.03 \\
\hline 2 & Manufacturing & 14.48 & 14 & 10 & 9.73 \\
\hline 3 & Construction & 13.73 & 12 & 16 & 9.75 \\
\hline
\end{tabular}

Source: (Alrabeei \& Kasi, 2014; Kasi, 2016; Naumann et al., 2018; MOICT, 2020)

Table 2 shows that most SMEs are trade-oriented (AlRabeei, 2003; AlRabeei \& Scott, 2011; $\mathrm{BCCl}, 2016$; Ravi, 2017), and they depend on simple operations and imported goods (Hertog, 2010; Ashoor, 2013; Naumann et al., 2018).

While Bahrain SMEs lack the ability to deal with business opportunities (Ravi, 2017) and do not concentrate regionally on promising opportunities (Alyafie \& AlMubarak, 2016; Dauphin et al., 2016), the entrepreneurs are risk averse (Bunagan \& Sison, 2018), driven by a too cautious temper (Lazell, 2012), and they lack self-confidence (AlGhazali et al., 2013). For these reasons, they focus on low-margin activities (Hertog, 2008; Dauphin et al., 2016; Alyafie \& AlMubarak), and perceive identifying business opportunities as useless (Kasi, 2016).

Collectively, the traditional preference of entrepreneurial endeavors has been vanishing amongst Bahrain nationals as they perceive it as a risky approach to gaining income (Alrabeei, 2003). Hence, many SMEs owners leave their own businesses and get employed by others due to the society influence (Meero \& Rahiman, 2018). Unsurprisingly, Jaffari (2004) reports that Bahrain SMEs perform well when they join foreign ventures, while they turn to perform in an adversely negative manner with family members.

\section{iv. SMEs Capabilities}

Although the complexity of Bahrain's business environment calls for acquiring adequate capabilities to enable the SMEs to increase their efficiency and operate competitively (Alrabeei, 2003; Alyafie \& AlMubarak, 2016), their capabilities are still inadequate.

Technologically, they use low-level setup (Dun \& Bradstreet, 2008) because they either could not afford to upgrade themselves or tend to undervalue their significance (AlRabeei \& Scott, 2011; Gillett, 2016; Alyafie \& AlMubarak, 2016). Furthermore, the weak internal financial management capabilities play a significant role in the conflict between SMEs and their lenders (Kaufman, 2013; Darwish, 2014; AlSoufi, 2016). The marketing capabilities are amongst the key challenges that Bahrain SMEs face even though the nation's area is small and $80 \%$ of the marketing expenses are supported by the government (Alrabeei \& Kasi, 2014; AlSoufi, 2016). The poor marketing practice negatively impacts the SMEs success in Bahrain (Alrabeei \& Kasi, 2014; Alrabeei \& Scott, 2014), and is believed to be conductive to many SMEs closures (Alsamari et al., 2013).

\section{v. Problem Solving and Decision Making}

SMEs are vulnerable to aggressive economic fluctuations in the business environment and fail within five years of establishment due to the inability to cope with that situation (Smit \& Atkins, 2012; Abu Bakar et al., 2016). Hence, they need to refigure their strategic orientation 
and possess essential problem-solving skills (Gillett, 2016), not only to survive but to use the rapid changes in building competitive advantage (Mahmood \& Abu Bakar, 2016).

In Bahrain, another factor found in the funding issue is the inability to solve problems and performing quick decision making (AlSoufi, 2016), as the SMEs are either unaware about the reality of the banks' concerns or they do know but unable to resolve and take the right decisions (Ravi, 2017). Surprisingly, the same observation is found in South Africa where the SMEs are encountered with complicated financing problem (Smit \& Atkins, 2012). For these reasons, Bahrain's SMEs are called to ensure the ability of responding simultaneously to the sudden issues, solving the problems quickly, and sorting out the business operations efficiently (Gillett, 2016); to enable a firm assuring further steps over peers and reserve a pioneer position (Darwish, 2014).

\section{vi. Leadership}

Leadership is likely accountable of various moral problems associated with the poor attitudes and values the employees embrace while performing duties (Bunagan \& Sison, 2018). However, it is found that Bahrain SMEs sector faces massive employee retention where workers keep transferring and seeking for higher wages after getting the necessary training and experience (AIRabeei \& Scott, 2011). This phenomenon is merely associated with expats during the first three years of employment, the most critical period to any establishment. Hence, many startups could not adapt, and decide to quit (Albilad, 2019). Beyond the wages, it is reported that SMEs owners embrace improper leadership behavior by ignoring their businesses and do not supervise the employee directly (Alsamari et al., 2013; Bunagan \& Sison, 2018).

Empirically, it is found that the Transformational Leadership has direct influence over production as well as the employees in Bahrain (Birasnav et al., 2013; Bunagan \& Sison, 2018), because embracing positive leadership style enables SMEs to build creative working environment and inspire the employees to disclose their distinctive initiatives (Alrabeei, 2003). Therefore, creating such environment through a sophisticated leadership style would lead to the control of employees' retention problem and improve the production within those SMEs, and. hence, rescue them from failure.

\section{Discussion}

The paper focuses on the challenges face by SMEs. The detailed study of extant literature states that the different problems confront by the SMEs pursuit could be categorized as internal and/or external. While the internal challenges refer to the issues which are inherited within a firm and are commonly considered controllable by the firm (Fatoki, 2014). The external challenges refer to the issues found surrounding a firm's business environment and are considered uncontrollable by the firm (Paul et al., 2017; Wang, 2016).

The findings of this study corroborate the findings of prior review studies which reveal that all the internal challenges are managerial issues (Gabrielsson \& Gabrielsson, 2013; Farsi \& Toghraee, 2014; Agwu, 2014). Moreover, these findings (related to resources management, entrepreneurial behavior, SMEs capabilities, problem solving, and leadership) are attributed to Penrose's internal view of the firm and the Resource-Based View (RBV). While Penrose's states that the lack of internal capabilities causes obstacles to growth (Nair et al., 2008), the 
popular efficiency-based approach (RBV) stands on inside-out management's observation and actions to overcome the internal obstacles (Madhani, 2010; Matute, 2012). In other words, both views posit that the internal obstacles are managerial tasks. Therefore, the first proposition would be:

1- All the internal challenges of SMEs could be controlled by high managerial competencies.

The second portion of the findings constitutes of external challenges which corroborate other studies which posit that business environment (Sanyal et al., 2020), environmental dynamism (Paul et al., 2017), fierce competition (Gunerergin et al., 2012; Fatoki, 2014; Tran, 2015; AlMaskari et al., 2019) and social influence (Pollard \& Jemicz, 2010; Ellis, 2011; Cant \& Wiid, 2013) are major challenges today.

Compared to RBV, the dynamic capabilities view (DCV) is another efficiency-based approach but paid higher consideration to external threats and opportunities that exists in the contemporary rapidly changing environment (Matute, 2012). In reality, SMEs could not work within high level of complexity, such as that found in Bahrain's business environment, without possessing dynamic capabilities DCs (Schoemaker et al., 2018). Teece et al., (1997) define DCs as "the firm's ability to integrate, build, and reconfigure internal and external competences to address rapidly changing environments", while managers are considered as the key players because they are accountable for recognizing the need and responding to the change in the environment (Teece, 2016).

Several researchers posit that the external challenges could be controlled by SMEs either partially (Džafić et al., 2011; Vrande et al., 2019) or completely (Paul et al., 2017). Cant and Wiid (2013) contend that the challenge now is to improve the capabilities of SMEs to ensure their success. Likewise, Paul et al (2017) suggest that developing the capabilities of SMEs could help them overcome external obstacles. Similarly, Gabrielsson \& Gabrielsson (2013) develop a dynamic model explaining the growth and survival of SMEs within the dynamic environment by responding to the opportunities and threats as to reconfigure the internal capabilities and resources. Explicitly, Pissarides (1999) postulate that the flexibility of SMEs allows them to adapt to difficult condition imposed by substandard infrastructure, or imperfections in the regulatory environment.

Consequently, this study concludes that the external challenges such as dynamism, fierce competition, rapidly changing environment, infra, and regulations are also managerial concerns; and, thus the second proposition is speculated:

2- The external challenges could be mitigated through dynamic capabilities.

SMEs literature indicates that SMEs are asymmetric in terms of the problems they face (Latha \& Murthy, 2009; OECD, 2017). From the first glance, a researcher might think resources availability and infrastructure's status are the developing nations' major challenge. Nonetheless, many developing countries neither have problem with resources availability nor infrastructure but with corresponding management (Ramukuma, 2014; Farsi \& Toghrae, 2014; Džafić et al., 2011; Coad et al., 2012; Kumarasinghe, 2017; Al-Maskari et al. 2019).

Conversely, resources availability and infra state are among the key challenges in many developed countries (Wood et al., 2015; Kahiya \& Dean, 2016; Paul et al., 2017). Pissarides (1999) finds the weight of financial limitations in central and Eastern Europe is excessive and accountable for the unsatisfactory SMEs growth. Pissarides et al. (2003) report the flow of materials and financial constraints are challenging the SMEs in Russia and Bulgaria. Likewise, Kahiya \& Dean (2016) reveal SMEs in New Zealand face resource constraints. From USA, Wood 
et al (2015) cite that resource unavailability are amongst key problems that affect SMEs. In turn, Uden (2007) reports that SMEs in Europe are faced with infra problems.

Interventions also vary because some contexts might need developments while the other does not. To illustrate, Baporikar et al (2016) investigate alcoholic industry in Namibia and conclude that the SMEs neither need education nor experience to grow, but instead they need safety and fighting. Likewise, Coad et al (2012) consider the rural SMEs in India and conclude that they do not perceive infra as important.

Many scholars contend that the small size of SMEs itself is a problem. Paul et al (2017) posit comparing to large firms, small sized firms are confronted with greater challenges. Eggers (2020) clarifies that the smaller the firm the more likely it is vulnerable to internal and external obstacles: internally it employs less staff then is viewed ineligible to credit large fund, while externally, it is unable to achieve customers' demands. In terms of international trading a firm size decides how trade obstacles are observed (Kahiya \& Dean, 2016; Kahiya et al., 2014). Coad et al (2012) mention that firms which join the market in a small quantity often remain small entities that struggle to grow or expand, and the matter that would finally lead to limit the return on investment and decrease in the number of the middle-sized category. Wang (2016) finds that the size is negatively correlated with a severe level of resources constraint. In other words, the larger the firm, the less likely it faces difficulties in securing resources.

Other researchers, however, asserted the smallness of SMEs has an edge because it allows for fast decision making and flexible internal processes (Paul et al., 2017), and their smallness allows for flexibility to deal with different internal and external challenges (Pissarides, 1999). Therefore, their size enables them for a behavioral strength, and this is what is expected. Interestingly, a significant linkage between SMEs sizes and Governments' support (GS) is noticed, as the GS is not necessarily helpful to every SME. While Mahajar and Yunus (2006) create that the attention toward government assistance is low, Bennett and Robson (2003) reveal that some SMEs perform well without support and vice versa. Likewise, Landau et al. (2016) conclude some SMEs are more active at accessing institutional support than others. Park et al (2019) found financial support does not necessarily help SMEs' performance. Equally, Wood et al (2015) suggest the monetary assistance does not seem to increase the willingness to exporting.

Surprisingly, the business support in some contexts has a negative impact on SMEs growth. While Brush et al (2009) discover most owners prefer to remain SME, Tsuruta (2020) clarifies that they do not increase their capital to maintain SMEs requirement and enjoy the support. These findings support Gebauer (2018) who resists SMEs are either non-growers or slow growers. It also justifies the "growth orientation" in some countries like Bahrain that provide tremendous support but suffer from increasing number of micro enterprises which neither contribute to the employment nor to the GDP.

Consequently, SMEs in both developing and developed countries suffer from resources and infra constrains, and there is no solution that could be generalized other than the behavioral development. Pissarides (1999)'s states there is no exclusive solution in terms of providing financial support that could help develop the SMEs or reduce the constraints as long as they embrace improper behaviors. Likewise, Andalib and Halim (2019) contend that the evolution and survival of SMEs are threatened by inhibitions that exist in the organization's management. Equally, Paul et al. (2017) mention that high organizational behavior could positively affect the profitability and productivity within SMEs. Therefore, the following proposition is speculated: 
3- The behavioral approach fits the intervention endeavors in any SMEs sector. The present study confirms that previous studies which posit the contemporary organizational behavior is centered on strategic processes which include innovation (Uden, 2007; Farsi \& Toghraee, 2014; Ericson et al., 2016), exploration and exploitation of opportunities; cover issues related to resources management and supply chain management (Sidhu et al., 2007). These processes reshape an organization as a whole in the way it responds to opportunities and threats (Paul et al., 2017), create advantages from crises (Eggers, 2020) and reconsider business support as an opportunity rather than a negative factor hindering the growth.

Besides, the investigation conducted in this study has validated previous studies which reveal that there is a social influence that affect the SMEs success (Pissarides, 1999; Paul et al., 2017). While Latha and Murthy (2009) found the moral support from acquaintances is the most important factor for SMEs success. Other researchers found SMEs that form alliances with foreign companies tend to perform better than those that rely on family members (Fernández \& Nieto, 2006; Ellis, 2011; Pollard \& Jemicz, 2010). In turn, Stevenson (1983) posit entrepreneurs consider "social values" rather than "social contract". Therefore, it is up to the entrepreneurial behavior in responding to the different social effects. Consequently, the study helps SMEs managers by providing entrepreneurial means that could enable them to manage their resources efficiently, focus on growth, and progress under different situations. Hence, the following proposition is added:

4- SMEs that embrace high entrepreneurial behavior tend to succeed and grow further. Many researchers believe SMEs are resources constraint organizations (Ramukuma, 2014). Despite the researchers who are biased towards the financial domain in investigating SMEs problems (Levy, 1993; Pissarides, 1999), most studies have reported that SMEs major problems are access to finance, skilled staff, and the availability of raw materials (Džafić et al., 2011; Coad et al., 2012; Gunerergin et al., 2012; Cant \& Wiid, 2013; Fatoki, 2014; Ramukuma, 2014; Agwu, 2014; Tran, 2015; Wang, 2016; Ericson et al., 2016; Serefoglu \& Gokkaya, 2017; Kumarasinghe, 2017; Battistella et al., 2018; Al-Maskari, 2019; Sanyal et al., 2020).

Paul et al (2017) mention that, unlike large firms, SMEs lack the ability to build a base of resources and capabilities overtime and, hence, they cannot benefit from crucial concepts such as economies of scale and scope, financial and technological resources. Although not having access to finance is widely cited, it is not an ultimate problem, because it stems either from SMEs financial management (i.e. financial planning, accounting practices, and book keeping) or the management ability to effectively communicate and solve the banking documentation requirements (Ilua, 2009; Tran, 2015; Wang, 2016).

Wang (2016) found that the less experienced managers are more likely to perceive access to finance as a significant obstacle than those who are more experienced. Similarly, Beck and Demirguc-Kunt (2005) confirm Levy's (1993) who states that the miscommunication between borrowers and lenders is beyond the financing availability to SMEs. Likewise, Eggers (2020) found there is interconnectedness between finance availability and SMEs management strategy.

Smit and Atkins (2012) investigate the problem in South Africa then conclude that the SMEs are encountered with complicated financing problems due to the SMEs' inability to solve 
problems while dealing with the bankers. Likewise, Tran (2015) believes SMEs' main problem is lacking the managerial skills to operate businesses and dealing with problems. Conversely, Latha and Murthy (2009) reveal SMEs perform well when they solve the problems by themselves. For instant, to solve the smallness in front of the hugeness of the multinational companies, SMEs are advised to adopt join-venturing and effective networking. Sophisticated communication skills are also recommended (Uden, 2007).

These findings validate Porter's (1980) recommendation in using internal resources and skills as strength to counter threats and maximize the opportunities in the external environment. Consequently, the problem of access to finance belongs to the SMEs management ability has been concluded to solve the problems, and the following proposition is speculated:

5- SMEs that possess problem solving ability perform better than others.

Human resources are also widely cited (Pissarides, 1999; Džafić et al., 2011; Cant \& Wiid, 2013; Agwu, 2014; Tran; 2015; Battistella, 2018; Al-Maskari et al., 2019). Nonetheless, this study agrees with Paul et al. (2017) who reveal that the case of SME failure is attributed to ignoring their employees. Explicitly, it is believed leadership responsibility (Farsi \& Toghraee, 2014), technical staffing (Serefoglu \& Gokkaya, 2017), developing functional skills and staff training (Fatoki, 2014), as well as creating optimal working environment are essential to get the maximum output out of the employees (Senyucel, 2009). Therefore, the sixth proposition is offered:

6- SMEs could overcome the human resources issues and obtain superior employees performance by embracing a positive leadership style.

\section{Behavioral Model}

SMEs sectors constitute the most dynamic firms (Pissarides, 1999). Thus, managing a business within a very dynamic environment using traditional strategies is no longer sufficient (Teece, 2007). Rather, developing dynamic capabilities is paramount (Schoemaker, Heaton \& Teece, 2018).

Preceding discussion indicates that the SMEs organizational behavior is the key reason in responding to different external and internal challenges. Therefore, the dynamic capabilities view (DCV) is adapted to understand those challenges and a behavioral model is suggested.

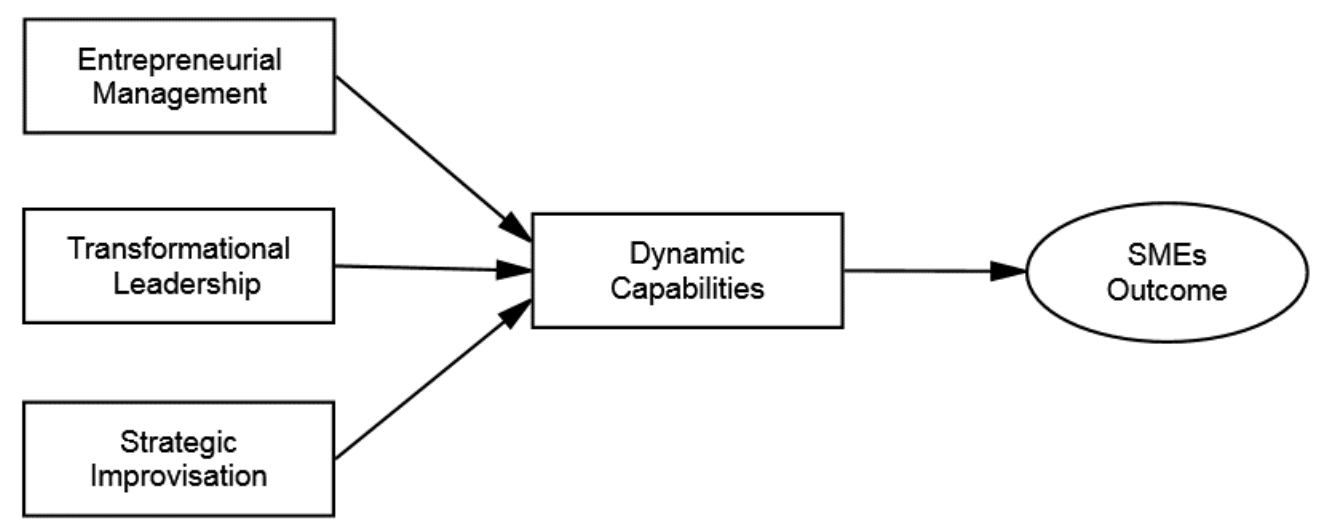

Figure-2 Behavioral Framework Model

DCV is an organizational behavioral theory (Augier \& Teece, 2009) which is used as a framework in the strategic management field and/ or as a variable construct (dynamic capabilities DCs) that offers a set of strategies that enable firms to succeed during fluctuating business environment, as illustrated in figure 2. However, the DCs need a third hand to 
frequently shape the firm's capabilities and resources in response to opportunities and changes in the business environment (Teece, 2007; Augier \& Teece, 2009; Schoemaker, Heaton \& Teece, 2018). The third hand is the manager or team of management (Teece, 2016) performing three roles mentioned in table 3 .

Table-3 Managers' Roles

\begin{tabular}{|l|l|l|l|}
\hline & Entrepreneurial role & \multicolumn{1}{|c|}{ Leadership role } & \multicolumn{1}{|c|}{ Strategic role } \\
\hline Responsibilities & Sensing and seizing & $\begin{array}{l}\text { Propagating vision and } \\
\text { values }\end{array}$ & $\begin{array}{l}\text { Planning } \\
\text { budgeting }\end{array}$ \\
\hline Activities & $\begin{array}{l}\text { Orchestrating } \\
\text { resources }\end{array}$ & $\begin{array}{l}\text { Aligning people with } \\
\text { strategy }\end{array}$ & Organizing and staffing \\
\hline Levers & $\begin{array}{l}\text { Investing in R\&D, } \\
\text { developing new } \\
\text { business models }\end{array}$ & Motivating people & $\begin{array}{l}\text { Control and problem } \\
\text { solving }\end{array}$ \\
\hline Goals & $\begin{array}{l}\text { Competitive } \\
\text { advantage }\end{array}$ & Unity of purpose & $\begin{array}{l}\text { Technical efficiency } \\
\text { and predictable results }\end{array}$ \\
\hline $\begin{array}{l}\text { Suggested } \\
\text { construct }\end{array}$ & $\begin{array}{l}\text { Entrepreneurial } \\
\text { Management }\end{array}$ & $\begin{array}{l}\text { Transformational } \\
\text { Leadership }\end{array}$ & Strategic Improvisation \\
\hline
\end{tabular}

Source: Teece (2016)

The first role is taken up by EM that is responsible for sensing opportunities and shifting in the business environment so as to synchronize the resources required for the purpose of exploiting promising trends or tracing social needs (Stevenson, 1983), and to design strategies that aid in adjusting the firm and its business style (Stevenson \& Jarrillo, 1990). These tasks are supposed to be harmonized throughout the entire firm so as to achieve superior growth and performance (Stevenson \& Gumper, 1985). The influence of EM is proven in terms of value creation on both firms and countries because it is rooted to the opportunity-based entrepreneurship, the most influential form amongst entrepreneurship theories in the economic development (Ghura et al., 2017).

The second role is played by TL who would consider the last point where modern leadership theory has reached (Tiftik, Kılıç \& Sağlam, 2015) and is ideal for both leaders and subordinates regardless of their backgrounds (Arham, 2014). TL enables an organization to adapt to the requirements and opportunities of the targeted business environment (Teece, 2016). While an entrepreneur articulates the organizational vision to prospect the future (Stevenson, 1983), leaders are devoted to get others involved in a common-vision, shared accountability, unified framework, and to stimulate the entire organization towards success (Bass, 1985). These effects are desirable if an organizational transformation is to be successful (Augier \& Teece, 2009). Higher organizational performance is guaranteed by applying the principles of TL (Teece, 2016).

The third role stated by Teece (2016) is "operational role". However, since it is concerned with control of resources, problem solving, and predicting results (Teece, 2016), it resembles the role of "Strategic Improvisation (SI)" which stands on managers' ability to respond to unforeseen circumstances intelligently and effectively; corresponding to limited time and resources in order to solve a problem or utilize an opportunity beyond routines (Ibrahim et al., 2016). Moreover, Teece (2012:p.1395) states "within a dynamic enterprise that seeks CA, 
there is an important role for manager need to be filled and related to generis strategic acts that neither stem from routines, nor give rise to new routines". Therefore, the study, devise it to SI to better represent Teece's (2012) statement.

$\mathrm{SI}$ is regarded as a source of CA because its creativity enables an SME to adapt in any changing environment and increases its performance (Mahmood \& Abu Bakar, 2016). Figure 3 matches the themed problems found in the current study (findings) with the corresponding constructs which are mentioned in the model of the current study.

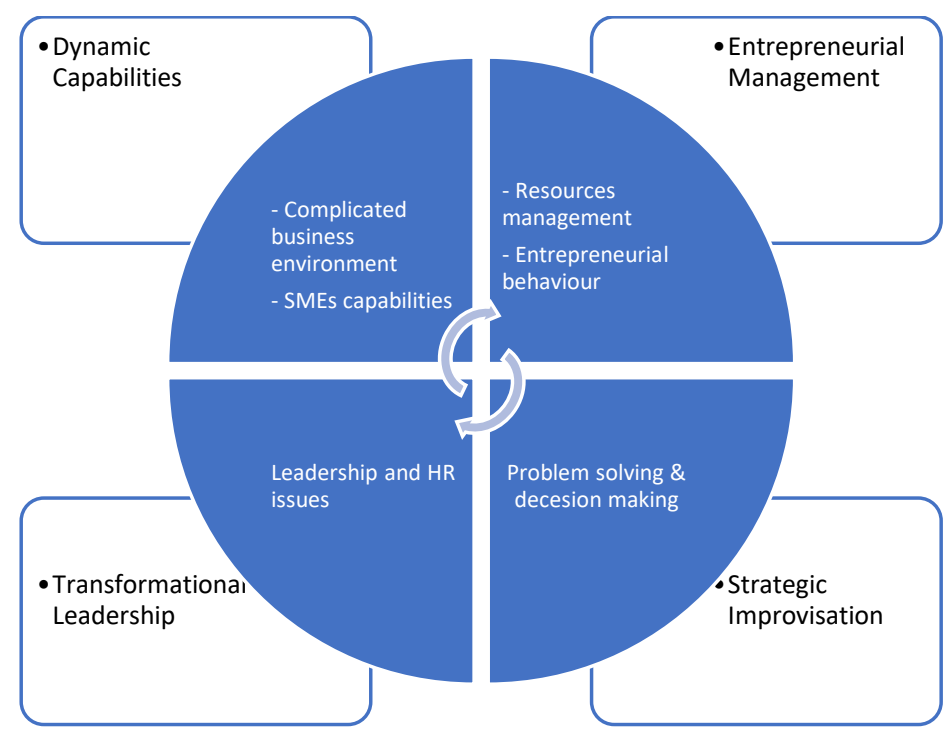

Figure-3 Linking Findings of the Study with the Suggested Constructs

\section{Conclusion}

Bahrain has adopted a series of promising policies in order to foster the SMEs sector, by investing in a number of legal and economic frameworks that support a robust entrepreneurship ecosystem. These efforts are accredited by several third-parties. However, the contribution of SMEs to the national socioeconomic developments falls significantly below the global average.

The primary goal of this study was to determine the key challenges that specifically hinder Bahrain's SMEs from performing well. The findings indicate that social influence, dynamism of market, and the fierce competition are key external factors that affect Bahrain SMEs. Conversely, the weak resources management, lack of entrepreneurial behavior, inefficient SMEs capabilities, dearth skills of problem solving and decision making, as well as the improper leadership styles are the internal factors. This study has also aimed to verify the different challenges that exist in the literature to realize whether those problems are controllable. Favorably, it is concluded that SMEs could control internal challenges and mitigate the external ones. Consequently, we recommend embracing appropriate strategies and skills encompassed in the proposed theoretical framework as overcome the internal and external challenges, as mentioned in figures 2 and 3.

It is noteworthy that Bahrain's business environment is found to be complicated; small, open, free, dynamic, and encompasses fierce competition. While the entrepreneurial endeavors are viewed risky and unappreciated by Bahrain nationals. Accordingly, Bahrain's SMEs capabilities are inefficient to deal with the level of complexity that exists in business environment. Furthermore, although SMEs leaders lack the ability to respond quickly and strategically to 
the different problems they face, they miss the proper attitude and values in operating their business. In particular, they are hesitant, risk-averse, and too cautious. For these reasons, Bahrain SMEs are faced with difficulties in securing and controlling the necessary resources in terms of human resources and finance.

Bahrain SMEs lack the organizational strategy. Externally, they lack the ability to build industrial networking and relationships. Internally, they lack both planning and the ability to set forth clear business visions. Therefore, they lack the ability to deal with business opportunities, and never consider the fact that promising opportunities arise from times to time in the GCC region. Instead, they merely focus on traditional low-margin business activities. Technically, the innovativeness amongst Bahrain SMEs is unpleasing. Although the SMEs sector is skewed towards the trading sector which depends on importing finished goods and services, the number of local manufacturing companies is constantly decreasing over the years.

Looking from a wider angle, Bahrain SMEs sector constitutes of two groups, some are unlikely to grow; the other ones, however, are enthusiastic but lack the operational strategy to do so. As a result, the country's officials are not happy with this condition and urge for a worthwhile middle sector that could derive growth of economy in terms of production, exportation and employment.

Interesting issues have been highlighted in this paper. Although inaccessibility to finance is one of the most cited problems, it is discovered that this problem is attributed to the internal management capabilities and their inability to successfully communicate with lenders and/ or fulfilling their documentation requirements. Moreover, many SMEs prefer to remain SME and do not tend to expand or to grow; because they prefer to enjoy the support provided by the sponsors. Above all, previous studies are corroborated with the present study and state the SMEs are asymmetric in terms of the problems they face and the solutions they need. For these reasons, instead of identifying a unique solution to every SME, the behavioral model proposed by current study could fit the SMEs challenges regardless of the context they exist in.

\section{Theoretical Implications}

This paper sheds light on the understanding of various theoretical and methodological aspects related to the challenges and modeling of SMEs literature.

The existing literature draws a generic opinion which states that the shortcoming of resources and infra is a developing countries' problem, while the developed countries are faced with an advanced-level of problems. Indeed, the investigation reveals that no such pyramid of challenges exists, as there is a number of developed countries which suffer from infra and resources challenges though many developing countries have no such issues. Moreover, various studies have arbitrarily generalized narrow solutions to the whole body of SMEs literature. However, it is found that every context has its unique challenges and needs; requisite solutions in some contexts found insignificant in the others.

In addition, the literature is full of biased findings, because of the dependence on the practitioners, without any consideration to other stakeholders. Such studies have been conducive to unbalanced conclusions that are sharply inclined to external parameters. 
Besides, it is found that many papers tend to focus on listing as much as possible of problems, assuming that such method would enable providing a solution to every single problem, even though the day-to-day business contains countless problems. Consequently, it is suggested reporting the major challenges, and involving different parties and sources during data collection are crucial, and more attention should be given to the SMEs behaviors as to enable them deal with the different problems independently.

\section{Practical Implications}

This study suggests that in order to grow and expand; Bahrain SMEs are advised to look for more opportunities at targeted market, locally and regionally. Business opportunity is not limited in innovating new products, but also by modifying and reviving of classic products, or targeting new customers in new clusters. Moreover, to mitigate local obstacles such as competition and access to resources, the SMEs are advised to think internationally by forming alliances, partnerships, outsourcing or sub-contracting with different GCC companies or/and seeking alternative source of resources.

Additionally, this study urges SMEs to keep reconfiguring their capabilities in response to the rapid developments in technology, operation methods, and marketing. Emphasis should be given on revising the internal capabilities of firms, which frequently is imperative against any unanticipated dilemma; COVD-19 pandemic is a concrete proof. Bahrain SMEs are also called to deal with the different problems simultaneously through strategic actions. They are urged to rethink about having true planning and clear vision centered on the company's objectives.

Since the SMEs sector suffers from enormous employees' retention, embracing transformational leadership is recommended to enable SMEs build creative working environment that motivate the employees and inspires them to perform beyond the expectations. TL should leads to control the retention problem, hence rescue SMEs from failure.

It is reported that there is scarcity of skilled workers, hence, local institutes are called to revise their programs so as to fulfill the up-to-date market needs. The lack of entrepreneurial training has significant negative impact on SMEs performance (Alsamari et al., 2013). Finally, this study highlights the importance of nurturing entrepreneurial spirit amongst people, thus, governments are called to stimulate solid entrepreneurial culture in order to instill a positive social-influence; to support the SMEs endeavors.

\section{Limitations and Future Research}

The current study highlights important propositions; yet, those propositions lack empirical testing. Therefore, future researches are encouraged to do so. Moreover, due to time constraints, the secondary sources are obtained without interviewing SMEs stakeholders for further clarifications. Thus, future researches are encouraged to complement their papers with primary data through focus groups, interviews, or semi-structured questionnaires.

The model in the present study draws insight on important relationships that could be examined to measure the effects of those factors on SMEs outcomes. Examining the prevalence of the behavioral constructs such as EM, TL, SI, and DCs amongst SMEs are other possible studies that need to be carried out to verify the level of organizational behavior 
amongst SMEs. Such attempts would enrich the behavioral approach because those constructs would enable the SMEs to understand the situation precisely.

\section{References}

Agwu, M. (2014). Issues, Challenges and Prospects of Small and Medium Scale Enterprises (SMEs) in Port-Harcourt City,. European Journal of Sustainable Development, 3(1), 101114. doi: 10.14207/ejsd.2014.v3n1p101

Akbar, F., Omar, A., Wadood, F., \& Al-Subari, S. (2018). The importance of SMEs, and furniture manufacturing SMEs in Malaysia: a review of literature. International Journal of Business Management, 2, 119 - 130.

Albilad. (2019). The first Arab to be awarded the International Academy of Productivity. Retrieved from http://www.albiladpress.com/newspaper/3834/565788.html

Al-Dairi, A., McQuaid, R., \& Adams, J. (2012). Entrepreneurship training to promote start-ups and innovation in Bahrain. International Journal of Innovation and Knowledge Management in Middle East \& North Africa, 1(2), 179-210.

AlGhazali, B., Md Yusoff, R., \& Sadi, M. (2013). Women Entrepreneurs in Bahrain: Motivations and Barriers. Jurnal Teknologi, 64(2), 139-143. doi: 10.11113/jt.v64.2251

Al-Maskari, A., Al-Maskari, M., Alqanoobi, M., \& Kunjumuhammed, S. (2019). Internal and external obstacles facing medium and large enterprises in Rusayl Industrial Estates in the Sultanate of Oman. Journal of Global Entrepreneurship Research,9(1). doi: 10.1186/s40497-018-0125-3

Alrabeei, H. (2003). The future of entrepreneurship and SMEs in Bahrain. In World conference, the 48th international council for small business (pp. 1-28). Belfast, UK: International council for small business (ICSB).

Alrabeei, H., \& Kasi, B. (2014). Barriers to growth : key challenges facing Bahraini small and medium enterprises. Oman chapter of Arabian Journal of Business and Management Review, 4(3), 45-62. http://dx.doi.org/10.12816/0019051

Alrabeei, H., \& Scott, J. (2011). Bahraini SMEs: why think local? Think global. Challenges facing Bahraini SMEs and internationalization. In The 56th international council for Small business (ICSB). Stockholm: World Conference.

Alrabeei, H., \& Scott, J. (2014). The effectiveness of business support in overcoming barriers facing Bahraini SMEs: the development of a business support effectiveness index. In International council for small business and entrepreneurship (ICSB) conference, Dublin (pp. 1-21). Teesside, UK: TeesRep.

Alsamari, A., Slade, H., Sharif, M., \& Saleh, W. (2013). The SMEs challenges and opportunities in Bahrain and Saudi Arabia. International Journal of Computer Networks and Wireless Communications, 3(2), 107-118.

AlSoufi, K. (2016). A new breed: Bahrain's SME sector - American chamber of commerce in Bahrain. Retrieved from http://www.amchambahrain.org/2016/02/07/a-new-breedbahrains-sme-sector-is-adapting-to-a-new-economic-landscape-with-more-agility/

Alyafie, A., \& Al-Mubarak, M. (2016). Challenges of going global for SMEs. International Journal of Innovation and Knowledge Management in Middle East and North Africa, 5(1), 1-11.

Andalib, T., \& Halim, H. (2019). Convergence of Conceptual Innovation Model to Reduce Challenges Faced by the Small and Medium Sized Enterprises' (SMEs) in Bangladesh. Journal of Open Innovation: Technology, Market, and Complexity, 5(3), 63. doi: $10.3390 /$ joitmc5030063 
Arham, A. (2014). Leadership and performance: the case of Malaysian SMEs in the services sector. International Journal of Asian Social Science, 4(3), 343-355. ISSN(e): 2224-4441

Augier, M., \& Teece, D. (2009). Dynamic Capabilities and the Role of Managers in Business Strategy and Economic Performance. Organization Science, 20(2), 410-421. doi: 10.1287/orsc.1090.0424

Ashoor, A. (2013). The structure of SME in the GCC and how are they promoted. In Arab-EU event (pp. 1-49). Doha: Arab development portal. Retrieved from http://www.arabdevelopmentportal.com/publication/structure-smes-gcc-and-howare-they-promoted

Battistella, C., Cagnina, M., Cicero, L., \& Preghenella, N. (2018). Sustainable Business Models of SMEs: Challenges in Yacht Tourism Sector. Sustainability, 10(10), 3437. doi: 10.3390/su10103437

Bahrain Chamber of Commerce and Industry, B. (2016). Towards a unified strategy for supporting small and medium sized enterprise (pp. 11-52). Manama: Third wave international.

Bass, B. (1985). Leadership and performance beyond expectations. New York, NY: Free Pr.

Baporikar, N., Nambira, G., \& Gomxos, G. (2016). Exploring factors hindering SMEs' growth: evidence from Nambia. Journal of Science and Technology Policy Management, 7(2), 190 211. doi: 10.1108/jstpm-11-2015-0036

Bennett, R., \& Robson, P. (2003). Changing use of external business advice and government supports by SMEs in the 1990s. Regional Studies, 37(8), 795-811.

Birasnav, M., Albufalasa, M., \& Bader, Y. (2013). The role of transformational leadership and knowledge management processes on predicting product and process innovation: An empirical study developed in Kingdom of Bahrain. Tékhne,11(2), 64-75. doi: 10.1016/j.tekhne.2013.08.001

BNA. (2013). 4th SMEs conference begins. Retrieved from https://search.proquest.com/docview/1466306091 ?accountid $=27932$

BNA. (2018). Industry Minister launches Export Bahrain. Retrieved from https://www.bna.bh/en/IndustryMinisterlaunches percentE2 percent80 percent98ExportBahrain percentE2 percent80 percent99.aspx?cms=iQRpheuphYtJ6pyXUGiNqmZfoBHQBVIs

Bunagan, V., \& Sison, S. (2018). Entrepreneurial Culture and Orientations of SME Owners/Managers in the Kingdom of Bahrain. In Entrepreneurship and Innovation (pp. 112). Manama: Kingdom University, Bahrain.

Cant, M., \& Wiid, J. (2013). Establishing the Challenges Affecting South African SMEs. International Business \& Economics Research Journal (IBER), 12(6), 707. doi: 10.19030/iber.v12i6.7869

Chaaban, F. (2015). The little island with big ideas. Retrieved from https://www.entrepreneur.com/article/245363

Coad, A., \& Tamvada, J. (2011). Firm growth and barriers to growth among small firms in India. Small Business Economics, 39(2), 383-400. doi: 10.1007/s11187-011-9318-7

Darwish, S. (2014). The role of universities in developing small and medium enterprises (SMEs): future challenges for Bahrain. International Business and Management, 8(2), $70-$ 77. doi: $10.3968 / 4776$

Dauphin, J., Ndela, J., Fang, X., \& Auclair, G. (2016). Economic diversification in oil-exporting Arab countries. In Annual meeting of Arab ministers of finance (pp. 3-40). Manama: International monetary fund. 
Džafić, Z., Zahirović, S., \& Okičić, J. (2011). Internal and External Obstacles to the Development of SMEs in Bosnia and Herzegovina. Croatian Economic Survey, 13(1), 143-171.

Beck, T., Demirguc-Kunt, A., \& Levine, R. (2005). SMEs, growth, and poverty: Cross-country evidence. Journal of Economic Growth, 10(3), $199 \mathrm{e} 229$.

Brush, C., Ceru, D., \& Blackburn, R. (2009). Pathways to entrepreneurial growth: The influence of management, marketing, and money. Business Horizons, 52(5), 481-491. doi: 10.1016/j.bushor.2009.05.003

Dun \& Bradstreet. (2008). Study of the Key Problems \& Challenges of SMEs in Bahrain.

Dutta, A. (2017). Innovation in Microenterprises: Case of Women Entrepreneurs in the Kingdom of Bahrain. Journal of Empirical Research in Accounting \& Auditing, 04(01), $70-$ 82. doi: 10.12785/jeraa/040104

Economic Development Board (2018). Bahrain Economic Quarterly, 1st quarter, September (pp. 2-39). Manama.

Eggers, F. (2020). Masters of disasters? Challenges and opportunities for SMEs in times of crisis. Journal of Business Research, 116, 199-208. doi: 10.1016/j.jbusres.2020.05.025

Ellis, P. (2011). Social ties and international entrepreneurship: Opportunities and constraints affecting firm internationalization. Journal of International Business Studies, 42(1), 99127.

Ericson, A., Holmqvist, J., Wenngren, J., Kaartinen, H., \& Solvang, W. (2016). SMEs' challenges and needs in relation to innovation agendas and strategies. 2016 International Symposium on Small-Scale Intelligent Manufacturing Systems (SIMS). doi: $10.1109 /$ sims.2016.7802893

Fatoki, O. (2014). The Causes of the Failure of New Small and Medium Enterprises in South Africa. Mediterranean Journal of Social Sciences, 5(20), 922-927. doi: 10.5901/mjss.2014.v5n20p922

Fernández, Z., \& Nieto, M. J. (2006). Impact of ownership on the international involvement of SMEs. Journal of International Business Studies, 37(3), 340-351.

Gabrielsson, P., \& Gabrielsson, M. (2013). A dynamic model of growth phases and survival in international business-to-business new ventures: The moderating effect of decisionmaking logic. Industrial Marketing Management,42(8), 1357-1373. doi: 10.1016/j.indmarman.2013.07.011

Gebauer, J. (2018). Towards Growth-Independent and Post-Growth-Oriented Entrepreneurship in the SME Sector. Management Review, 29(3), 230-256. doi: 10.5771/0935-9915-2018-3-230

Günerergin, M., Penbek, Ş., \& Zaptçıoğlu, D. (2012). Exploring the Problems and Advantages of Turkish SMEs for Sustainability. Procedia - Social and Behavioral Sciences, 58, 244-251. doi: 10.1016/j.sbspro.2012.09.998

Ghura, H., Li, X., \& Harraf, A. (2017). Moderating relationship of institutions for opportunity entrepreneurship and economic development. World Journal of Entrepreneurship, Management and Sustainable Development, 13(4), 350-374. doi: 10.1108/wjemsd-062017-0031

Gillett, K. (2016). Small businesses in Bahrain: 15 inspiring entrepreneurs in Bahrain share their big ideas. Retrieved from https://www.timeoutbahrain.com/aroundtown/features/74186-small-businesses-inbahrain 
Hamdi, H., \& Sbia, R. (2013). Dynamic relationships between oil revenues, government spending and economic growth in an oil-dependent economy. Economic Modelling, 35, 118-125. doi: 10.1016/j.econmod.2013.06.043

Hasan, F., \& Almubarak, M. (2016). Factors influencing women entrepreneurs' performance in SMEs. World Journal of Entrepreneurship, Management and Sustainable Development, 12(2), 82-101. doi: 10.1108/wjemsd-09-2015-0037

Hertog, S. (2010). Benchmarking SME policies in the GCC: a survey of challenges and opportunities (pp. 1-50). European commission.

Ibrahim, N., Mahmood, R., \& Abu Bakar, M. (2016). Strategic improvisation and entrepreneurial self-efficacy constructs validation in Nigerian higher education institutions. MAYFEB Journal of Business and Management, 1, 37-42.

Ihua, U. (2009). SMEs Key Failure-Factors: A Comparison between the United Kingdom and Nigeria. Journal of Social Sciences, 18(3), 199-207. doi: 10.1080/09718923.2009.11892682

Jaffari, A. (2004). Performance of Manufacturing SMEs in Fluctuating Single Product Oil Economy - The Case of Bahrain (PhD). University of London.

Sidhu, J., Commandeur, H., \& Volberda, H. (2007). The Multifaceted Nature of Exploration and Exploitation: Value of Supply, Demand, and Spatial Search for Innovation. Organization Science, 18(1), 20-38. doi: 10.1287/orsc.1060.0212

Kasi, R. (2016). An Overview of Bahrain's SME Sector. In Proceedings of 11th Annual London Business Research Conference (pp. 1-11). Manama, Bahrain: Royal University for Women, Kingdom of Bahrain.

Kaufman, R. (2013). Bahrain SMEs Sector 'vital to economy. Tradearabia.com. Retrieved 26 April 2018, from http://www.tradearabia.com/news/EDU_248026.html

Khan, M., \& Khalique, M. (2014). An Overview of Small and Medium Enterprises in Malaysia and Pakistan: Past, Present and Future Scenario. Business and Management Horizons, 2(2), 38. doi: 10.5296/bmh.v2i2.5792

Khan, I., \& Nawaz, A. (2016). A comparative analysis of leadership theories: a review. Gomal University Journal of Research, (Special Issue IV), 20-31.

Khamis, A. (2016). A blueprint for the evolution of the SME sector In the Middle East. Retrieved from https://www.entrepreneur.com/article/286019

Kijkasiwat, P. (2021). The influence of behavioral factors on SMES' owners' intention to adopt private finance. Journal of Behavioral and Experimental Finance, 30, 100476. doi: 10.1016/j.jbef.2021.100476

Kumarasinghe, P. (2017). Hindering and fostering factors SMEs performance in the Western Province of Sri Lanka. International Journal of Management Excellence, 9(2), 1097. doi: 10.17722/ijme.v9i2.361

Landau, C., Karna, A., Richter, A., \& Uhlenbruck, K. (2016). Institutional leverage capability: Creating and using institutional advantages for internationalization. Global Strategy Journal, 6(1), 50-68.

Lavanya Latha, K., \& Murthy, B. (2009). Problems of small-scale entrepreneurs in Nellore District. Journal of Chinese Entrepreneurship, 1(3), 268-278. doi: 10.1108/17561390910999542

Lazell, M. (2012). Change of mindset among SMEs needed. Retrieved from http://www.tradearabia.com/news/REAL_226539.html

Levy, B. (1993). Obstacles to Developing Indigenous Small and Medium Enterprises: An Empirical Assessment. The World Bank Economic Review, 7(1), 65-83. 
Madhani, P. (2010). Resource based view (RBV) of competitive advantage: An overview. ICFAI business school.

Mahajar, A. J., \& Yunus, J. B. (2017). The Efectiveness of Government Export Assistance Programs on Malaysia Small \& Medium Enterprises (SMEs). Problems and perspectives in management, 4.

Mahmood, R., \& Abu Bakar, H. (2016). Examining strategic improvisation and performance relationship in the SMEs: moderating role of entrepreneurial self-efficacy. Medwell Journals, International Business Management, 10(13), 2535-2540.

Matute, C. (2012). Antecedents of dynamic capabilities: the role of entrepreneurial orientation and intellectual capital (Doctor of Management Science). EGADE Business School.

McCann, P., \& Ortega-Argilés, R. (2016). Smart specialization, entrepreneurship and SMEs: issues and challenges for a results-oriented EU regional policy. Small Business Economics, 46(4), 537-552. doi: 10.1007/s11187-016-9707-z

Meero, A., \& UrRahiman, H. (2018). An evaluation of the prospects of entrepreneurship development in Bahrain: a review. In Entrepreneurship and innovation (pp. 1-12). Manama: Kingdom university, Bahrain.

Ministry of Industry, Commerce, and Tourism. (2020). SMEs statistics in the Kingdom of Bahrain and sector figures impacted by Covid 19 (pp. 1-10). The Kingdom of Bahrain: Ministry of Industry, Commerce and Tourism.

Nair, A., Trendowski, J., \& Judge, B. (2008). The Theory of the Growth of the Firm, by Edith T. Penrose. Oxford: Blackwell, 1959 [book review]. Academy of Management Review, 33(4), 1026-1028.

Nakibullah, A. (2018). Economic diversification in Bahrain. Applied Economics and Finance, 5(5), 67. doi: 10.11114/aef.v5i5.3576

Nakibullah, A., \& Islam, F. (2007). Effect of government spending on non-oil GDP of Bahrain. Journal of Asian Economics, 18(5), 760-774. doi: 10.1016/j.asieco.2007.05.003

Naumann, C., Alubaydli, O., Abdulla, G., \& Alabbasi, A. (2018). Pathways to sustainable economic growth in Bahrain (pp. 57-94). Manama: Bahrain center for strategic, international and energy studies (Derasat).

Organisation for Economic Co-operation and Development. (2017). Enhancing the contribution of SMEs in a global and digitalized economy (pp. 1-24). Paris: OECD.

Park, S., Lee, I., \& Kim, J. (2019). Government support and small- and medium-sized enterprise (SME) performance: the moderating effects of diagnostic and support services. Asian Business \& Management, 19(2), 213-238. doi: 10.1057/s41291-019-00061-7

Paul, J., Parthasarathy, S., \& Gupta, P. (2017). Exporting challenges of SMEs: A review and future research agenda. Journal of World Business, 52(3), 327-342. doi: 10.1016/j.jwb.2017.01.003

Pissarides, F. (1999). Is lack of funds the main obstacle to growth? ebrd's experience with small- and medium-sized businesses in central and eastern Europe. Journal of Business Venturing, 14(5-6), 519-539. doi: 10.1016/s0883-9026(98)00027-5

Pissarides, F., Singer, M., \& Svejnar, J. (2003). Objectives and constraints of entrepreneurs: evidence from small and medium size enterprises in Russia and Bulgaria. Journal of Comparative Economics, 31(3), 503-531. doi: 10.1016/s0147-5967(03)00054-4

Pollard, D., \& Jemicz, M. (2010). Social capital theory and the internationalization process of Czech SMEs. International Journal of Economics and Business Research, 2(3-4), 210-229.

Porter, M. J. (1980). Competitive strategy: Techniques for analyzing industries and competitors. New York: Free Press. 
Ramukumba, T. (2014). Overcoming SMEs Challenges through Critical Success Factors: A Case of SMEs in the Western Cape Province, South Africa. Economic and Business review, 16(1), 19-38.

Ravi, M. (2017). Are Bahrain SMEs really a success?. Retrieved from http://www.gdnonline.com/Details/247328/Are-Bahrain-SMEs-really-a-success

Rubio, A., \& Aragón, A. (2009). SMEs Competitive Behavior: Strategic Resources and Strategies. Management Research: Journal of the Iberoamerican Academy of Management, 7(3), 171-190. doi: 10.2753/jmr1536-5433070301

Sadi, M., \& AlGhazali, B. (2012). The dynamics of entrepreneurial motivation among women: a comparative study of business women in Saudi Arabia and Bahrain. Asian Academy of Management Journal, 17(1), 97-113.

Sanyal, S., Hisam, M., \& Baawain, A. (2020). Challenges Facing Internationalization of SMEs in Emerging Economies: A Study on OECD Model. The Journal of Asian Finance, Economics and Business, 7(2), 281-289. doi: 10.13106/jafeb.2020.vol7.no2.281

Senyucel, Z. (2009). Managing the human resource in the 21 st century. London: Ventus Publishing ApS.

Serefoglu, C., \& Gokkaya, E. (2017). Challenges of rural SMEs IN Ankara, Turkey. Sustainable Development and Planning IX, 266(311-321). doi: 10.2495/sdp170271

Śledzik, K. (2013). Schumpeter's View on Innovation and Entrepreneurship. SSRN Electronic Journal. doi: 10.2139/ssrn.2257783

Smit, Y., \& Watkins, J. (2012). A literature review of small and medium enterprises (SME) risk management practices in South Africa. African Journal of Business Management, 6(21). doi: 10.5897/ajbm11.2709

Schoemaker, P., Heaton, S., \& Teece, D. (2018). Innovation, Dynamic Capabilities, and Leadership.California Management Review,61(1), 15-42. doi: 10.1177/0008125618790246

Stevenson, H. (1983). A Perspective on Entrepreneurship. Harvard Business School, 384-131.

Stevenson, H., \& Gumper, D. (1985). The heart of Entrepreneurship. Harvard Business Review, 85-94.

Stevenson, H., \& Jarrillo, J. (1986). Preserving entrepreneurship as companies grow. Journal of Business Strategy, 7(1), 10-23. doi: 10.1108/eb039138

Teece, D., Pisano, G., \& Shuen, A. (1997). Dynamic capabilities and strategic management. Strategic Management Journal, 18(7), 509-533.

Teece, D. (2007). Explicating dynamic capabilities: the nature and microfoundations of (sustainable) enterprise performance. Strategic Management Journal, 28(13), 13191350. doi: $10.1002 /$ smj. 640

Teece, D. (2012). Dynamic capabilities: routines versus entrepreneurial action. Journal of Management Studies, 49(8), 1395-1401. doi: 10.1111/j.1467-6486.2012.01080.x

Teece, D. (2014). A dynamic capabilities-based entrepreneurial theory of the multinational enterprise. Journal of International Business Studies,45(1), 8-37. doi: 10.1057/jibs.2013.54

Teece, D. (2016). Dynamic capabilities and entrepreneurial management in large organizations: Toward a theory of the (entrepreneurial) firm. European Economic Review, 86, 202-216. doi: 10.1016/j.euroecorev.2015.11.006

Tiftik, H., Kılıç, Ş., \& Sağlam, M. (2015). Leadership theories and comparison of them. Journal of Research in Business, Economics and Management (JRBEM), 4(2), 312-322. ISSN: 23952210 
Townsend, S. (2017). When it comes to Bahrain's SMEs, less is more. Retrieved from https://www.arabianbusiness.com/when-it-comes-bahrain-s-smes-less-is-more667332.html

Tran, H. (2015). Challenges of Small and Medium-Sized Enterprises (SMEs) In Vietnam during the Process of Integration into the ASEAN Economic Community (AEC). International Journal of Accounting and Financial Reporting, 5(2), 133. doi: 10.5296/ijafr.v5i2.8298

Tsuruta, D. (2018). SME policies as a barrier to growth of SMEs. Small Business Economics, 54(4), 1067-1106. doi: 10.1007/s11187-018-0119-0

Uden, L. (2007). How to Promote Competitive Advantages for SMEs: Issues, Ideas and Innovation. Journal of Business Systems, Governance and Ethics, 2(2), 1-15. doi: 10.15209/jbsge.v2i2.100

Van de Vrande, V., de Jong, J., Vanhaverbeke, W., \& de Rochemont, M. (2009). Open innovation in SMEs: Trends, motives and management challenges. Technovation, 29(67), 423-437. doi: 10.1016/j.technovation.2008.10.001

Wang, Y. (2016). What are the biggest obstacles to growth of SMEs in developing countries? An empirical evidence from an enterprise survey. Borsa Istanbul Review, 16(3), 167-176. doi: 10.1016/j.bir.2016.06.001

Wood, A., Logar, C., \& Riley, W. (2015). Initiating exporting: The role of managerial motivation in small to medium enterprises. Journal of Business Research, 68(11), 2358-2365. doi: 10.1016/j.jbusres.2015.03.043

World Bank. (2021). SME Finance. Retrieved from https://www.worldbank.org/en/topic/smefinance\#: :text=SMEs\%20account\%20for\%2 0the\%20majority,(GDP)\%20in\%20emerging\%20economies.

Farsi, Y. J., \& Toghraee, M. (2014). Identification the main challenges of small and medium sized enterprises in exploiting of innovative opportunities (Case study: Iran SMEs). Journal of Global Entrepreneurship Research, 2(1), 4. doi: 10.1186/2251-7316-24

Yanes-Estévez, V., García-Pérez, A., \& Oreja-Rodríguez, J. (2018). The Strategic Behaviour of SMEs. Administrative Sciences, 8(4), 61. doi: 10.3390/admsci8040061

Yoshino, N., \& Taghizadeh-Hesary, F. (2016). Major Challenges Facing Small and MediumSized Enterprises in Asia and Solutions for Mitigating Them. SSRN Electronic Journal, 120. doi: $10.2139 /$ ssrn. 2766242

Youssef, C., \& Luthans, F. (2007). Positive Organizational Behavior in the Workplace. Journal of Management, 33(5), 774-800. doi: 10.1177/0149206307305562

Závadský, J., Malá, D., Benčiková, D., Sedliačiková, M., \& Šatanová, A. (2020). Behavioral approach to quality: An empirical study in Slovak SMEs. Cogent Business \& Management, 7(1), 1794678. doi: 10.1080/23311975.2020.1794678 